\title{
The missing intangibles: nature's contributions to human wellbeing through place attachment and social capital
}

\author{
Yuki Yoshida $^{1}\left(\mathbb{0} \cdot\right.$ Hirotaka Matsuda $^{2} \cdot$ Kensuke Fukushi $^{3,4} \cdot$ Kazuhiko Takeuchi $^{3,5} \cdot$ Ryugo Watanabe $^{6}$
}

Received: 30 August 2020 / Accepted: 11 November 2021 / Published online: 1 January 2022

(c) The Author(s) 2021

\begin{abstract}
Communities in socio-ecological production landscapes and seascapes are aging and depopulating. While longstanding interdependence of humans and nature in such areas holds crucial hints for sustainable development, they continue to be undervalued by existing economic frameworks. We suspect omission of non-material nature's contributions to people (NCPs) as a possible reason for this undervaluation and focus on the intangible aspects of human-nature relationships: people's direct and emotional attachment to their land and interrelationships between close-knit human communities and a thriving natural environment. Field observations on Sado Island, Japan, and literature reviews informed our hypothesis that perceived nature, conceptual human-nature relationships, place attachment, and social relationships contribute to subjective wellbeing. Structural equation modeling of island-wide questionnaire responses confirmed our hypothesis. Nature contributes to wellbeing by enhancing place attachment and social relationships; ecocentrism contributes to greater values of perceived nature. Free-response comments elucidated how local foods and close interpersonal relationships enhance residents' happiness and good quality of life, as well as how aging and depopulation impact their sense of loneliness. These results lend empirical support to the understanding of human-nature interdependency in socio-ecological production landscapes and seascapes. In assessing their value to local residents and society at large, greater consideration should be given to intangible aspects of human-nature relationships and quality of life.
\end{abstract}

Keywords Human-nature relationships · Quality of life · Socio-ecological production landscapes and seascapes $\cdot$ Cultural ecosystem services $\cdot$ Non-material nature's contributions to people $\cdot$ Relational values

Handled by Moinul Islam, Kyushu University, Japan.

Yuki Yoshida

yoshida.yuki@nies.go.jp

1 Center for Climate Change Adaptation, National Institute for Environmental Studies, 16-2 Onogawa, Tsukuba, Ibaraki 305-8506, Japan

2 Department of Agricultural Innovation for Sustainable Society, Faculty of Agriculture, Tokyo University of Agriculture, 1737 Funako, Atsugi-shi, Kanagawa 243-0034, Japan

3 Institute for Future Initiatives, The University of Tokyo, 7-3-1 Hongo, Bunkyo-ku, Tokyo 113-0033, Japan

4 Institute for the Advanced Study of Sustainability, United Nations University, 5-53-70 Jingumae, Shibuya-ku, Tokyo 150-8925, Japan

5 Institute for Global Environmental Strategies, 2108-11 Kamiyamaguchi, Hayama, Kanagawa 240-0115, Japan

6 Sado City, 232 Chigusa, Sado City, Niigata 952-1209, Japan

\section{Introduction}

Human wellbeing has long been the objective of sustainable development and understood to depend on nature and nature's contributions to people (NCPs) (Kates et al. 2005; Díaz et al. 2015). However, imbalance of human and ecological systems continues to jeopardize nature and thereby the wellbeing of current and future generations (Steffen et al. 2015; IPBES 2019). Within this context, this study aims to tackle the undervaluation of NCPs in rural communities. Socio-ecological production landscapes and seascapes, or Satoyama-Satoumi land- and seascapes, are considered model societies of human-nature harmony (Takeuchi et al. 2016). Their multifunctional landscapes not only enhance human wellbeing and community resilience (Schippers et al. 2014; Ebi et al. 2020), but provide habitat for diverse flora and fauna (Takeuchi 2010). Moreover, longstanding interdependence of humans and nature holds crucial hints for our 
future (Takeuchi et al. 2016). But while intangible aspects of this relationship such as people's direct and emotional attachment to their land, or the interrelationships between close-knit human communities and a thriving natural environment remain scarcely understood (Biedenweg et al. 2017), many of these societies are challenged by the global phenomenon of rural depopulation and aging (UN DESA Population Division 2019). We suspect our societal focus on monetary values and the most materialistic NCPs (Yoshida et al. 2018) to be an underlying cause for their systemic decline.

\section{Why non-material NCPs?}

Discourse in the policy-making arena has focused on material aspects of the human-nature relationship (Muhar et al. 2017). Frameworks such as of ecosystem services are used in ways considered more objective, more conducive to monetization, and at the macro-level to rationalize the legitimacy of considering human-nature relationships in policy (Muradian 2013; Allasiw et al. 2016). Failing to address non-material human-nature relationships, however, can be counterproductive (Comberti et al. 2015) and detriment less tangible aspects of the human-nature relationship that are nonetheless critical to wellbeing (Rode et al. 2015). Moreover, these "less tangible" aspects of a place can be more important to inhabitants (Martín-López et al. 2012) and determine their environmental behavior (Gobster et al. 2007; Orenstein 2013).

In this paper, we use the term "intangible" to encompass the primarily non-material aspects of the human-nature relationship. The term originates from UNESCO's concept of intangible cultural heritages (Kurin 2007). No matter how crucial, intangible heritages are loaded with cultural meanings and significances (Lenzerini 2011) and may not be equally understood or appreciated by an outside group. Intangible human-nature relationships, too, are inarguably real, but may be best assessed through individuals' perceptions.

\section{Conceptual framework}

We hypothesize that non-material NCPs enhance peoples' subjective wellbeing. More specifically, we hypothesize that these NCPs take the form of place attachment and social relationships, and that peoples' conceptualizations of their relationship with nature predict the richness of these NCPs (Fig. 1). The rest of this introduction summarizes the literature (reviewed in greater detail elsewhere (Yoshida 2018)), which, in combination with field observations, informed our theoretical and empirical understandings of human-nature relationships. Subsequent sections will report on our postal questionnaire, which gathered quantitative and qualitative

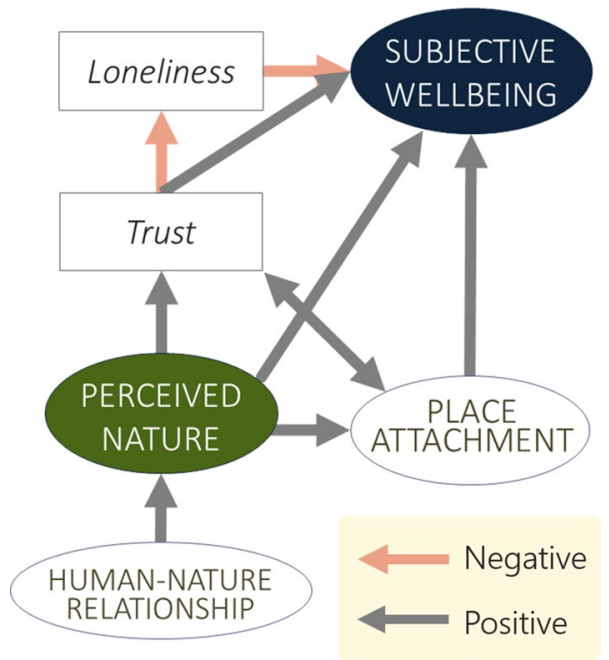

Fig. 1 Hypothesized model of how nature contributes to human wellbeing in the intangible human-nature relationship

data to examine one Satoyama-Satoumi community's experiences of the NCPs.

\section{Wellbeing and its determinants}

Wellbeing Wellbeing is a vast and dynamic concept, as is the literature on nature's benefits on human wellbeing. Studies have assessed direct influences of contact with nature on positive emotions (Tarrant 1996; Hartig et al. 2003; White et al. 2010) and life satisfaction (Kaplan and Stephen 1995; Vemuri and Costanza 2006). Similarly, connectedness with nature (Perrin and Benassi 2009; Cervinka et al. 2011) and works on nature-embedded constructs of wellbeing, such as the Ecuadorian Buen Vivir (Guardiola and García-Quero 2014) and Edward Wilson's Biophilia Hypothesis (Wilson 1984; Gullone 2000), suggest that human wellbeing benefits from inherent, or intrinsic, values of nature. The concept of relational values of nature, too, reframes the importance of the human-nature relationship to our wellbeing (Díaz et al. 2015; Chan et al. 2016).

Self-reported measures of wellbeing are influenced by some noise but considered reliable enough for empiric studies (Di Tella and MacCulloch 2006). Consistency of responses to various measures of subjective wellbeing has been verified across situations and time (Sandvik et al. 1993). Their convergent and discriminant validities have been demonstrated with behavioral and physiological correlates (Sandvik et al. 1993; Shedler et al. 1993; Di Tella et al. 2003; van Reekum et al. 2007), and an experimental study using various self-reported measures of wellbeing reported limited bias due to social desirability (Konow and Earley 2008). "Subjective wellbeing" is used here to refer to perceived wellbeing based on self-reports of respondents. 
The term is regularly used interchangeably with "happiness" and "life satisfaction" (Matsushima and Matsunaga 2015), and we adopt it here as an umbrella term for closely related constructs.

Notably, many moderators of seemingly direct NCPs, such as natural beauty (Zhang et al. 2014), health (Howell et al. 2011; Seymour 2016), and other psychological constructs, e.g., meaning in life (Howell et al. 2013), complicate the isolation of direct benefits from perceived nature to subjective wellbeing. We thus include a direct path from nature to subjective wellbeing in our analysis but focus on the moderation of these benefits through social relationships and place attachment (Fig. 1).

Social capital and loneliness Social capital is variously defined, but generally refers to the "norms and networks facilitating collective action for mutual benefit" (Michael Woolcock and Apr 1998, p. 155) and is often understood as social norms, trust, reciprocity, and civic engagement (Kawachi et al. 1997; Healy et al. 2001). Many studies link social capital to subjective wellbeing (Kuroki 2011; Bartolini and Sarracino 2014; Helliwell et al. 2016b) as well as to indirect determinants of wellbeing such as health (Kawachi et al. 1999; Rose 2000; Ziersch et al. 2005), economic productivity, democracy, and child welfare (Putnam 2000; Healy et al. 2001). Some specify that its impact on happiness may be stronger than that of education or income (Healy et al. 2001).

Following common practice, this study uses generalized trust (of unknown others) to operationalize social capital (Delhey et al. 2011). Social trust is one of the oldest and most available indicators for social capital (Helliwell et al. 2016a), correlates closely with other measures on civic engagement and social connectedness (Putnam 2000; Healy et al. 2001), and is known to yield policy-relevant results (Harper 2001; Bjørnskov 2006).

One impact of Sado's population decline on resident experiences may be increased isolation, resulting in loneliness, or feeling that one has "too few" social relationships (Russell et al. 1980, p. 472). At the same time, rural communities in areas such as Sado are known to be tight-knit and closed. As the intimacy of connections matter for loneliness more than sheer social contact (Baumeister and Leary 1995), social needs of well-immersed community members may be fulfilled despite a low population density. We consider loneliness in addition to generalized trust in light of its known, adverse impacts on wellbeing (Baumeister and Leary 1995) and pertinence to Sado's declining demography.

Place attachment Literature on place and place attachment is riddled by ambiguity and multiplicity of definition across academic disciplines. For compatibility with the breadth of topics we aimed to cover, we focused on the quantita- tive strength or importance of a person's bond with a place (rather than on the qualitative meanings of places) (Lewicka 2011). Further, place attachment is seen to have both functional and emotional attributes: place dependence and place identity, respectively (Williams et al. 1992). We draw upon Williams and Vaske's (2003) questionnaire, originally designed to assess place attachment within the context of recreational destinations, and since adapted for use in other contexts (Jorgensen and Stedman 2001; Brown and Raymond 2007).

Place attachment is known to improve subjective wellbeing. For example, Scannell and Gifford (2017) report on the various psychological benefits of place attachment. Residents of Swedish mountain communities who were more strongly attached to certain places reported a greater sense of wellbeing when visiting those places than residents who were less attached (Knez and Eliasson 2017). The emotional attachment, place identity, best predicted wellbeing in this study. Separation from place, such as through relocation, is reported to have adverse emotional and cognitive impacts on wellbeing (Scannell and Gifford 2017).

Perceived nature Perceived nature here refers to respondents' subjective evaluation of their natural surroundings. A forerunner in this regard was found in forestry, where early discussion questioning a commodified view of forests led to the suggestion that multiple values be considered in forestry management (Rolston and Coufal 1991). The list of values has been modified (Brown and Reed 2000; Brown 2005), adapted as landscape values, and empirically validated in multiple contexts beyond forestry (Brown 2003; Alessa et al. 2008; Cerveny et al. 2017). Mapping studies report partial to moderate overlap of landscape values with biophysical and ecological measures of the context (Brown 2005; De Vreese et al. 2016).

Conceptual human-nature relationships In the literature, "human-nature relationship" is used to refer to a spectrum of material and non-material relationships. Non-material aspects, the focus here, are variously referred to with terms such as values, value orientations, worldviews, connectedness with, visions of, and social representations pertaining to nature (Flint et al. 2013; Yoshida 2013; Muhar et al. 2017). We borrow van den Born's (2008) definition, "views that people hold about their appropriate relation with nature" (p. 87), which overlaps with many of these terms. Conceptual relationships with nature have been empirically linked with nature-relevant behaviors (Braito et al. 2016, 2020; Yoshida et al. 2017), and understanding of these cognitive, affective, and cultural relationships with nature is considered essential for promoting any change in the material relationship (Guerry et al. 2015). 


\section{Interrelationships among perceived nature and the NCPs}

Social capital and place attachment Past studies attest to a positive linkage between place attachment and social capital. For one, social relationships are encompassed within the concept of "place" in place attachment literature (Mesch and Manor 1998; Scannell and Gifford 2017). Other studies have examined the two as separate concepts and confirmed causality in both directions (Mesch and Manor 1998; Lewicka 2005; Stefaniak et al. 2017). Additional evidence suggests that positive influence of place attachment on social capital may be mediated by belongingness (Scannell and Gifford 2017). Place attachment may increase one's sense of belongingness by reinforcing feelings of embeddedness in the community and through symbolic connections with ones' ancestors or culture. This sense of belongingness is suggested to enhance the community's social capital through increased effectiveness of civic activities.

Perceived nature and social capital There is an extensive body of environmental psychology literature on the benefits of urban green spaces, one strand of which attests to its positive impact on social capital (Kweon et al. 1998; Sullivan et al. 2004; Wood and Giles-Corti 2008; Seeland et al. 2009; Holtan et al. 2014; Hadavi 2017). These studies broadly agree that green spaces enhance neighborhood social capital by facilitating social interactions. Green spaces are further reported to foster inclusive interactions (Seeland et al. 2009) and to flatten social inequities (Mitchell and Popham 2008). Both objective and subjective measures of nature have been used, and findings in rural settings have also come to consistent conclusions (Weinstein et al. 2015).

Social capital has also been discussed as an ecosystem service, i.e., NCP. The Millennium Ecosystem Assessment (2005) situates aspects of social interactions frequently used to measure social capital, such as social relations, cohesion, and interactions, as components of human wellbeing. Subsequent discussions of cultural ecosystem services led to the explicit inclusion of social capital and cohesion as one of the cultural services provided by ecosystems (Chan et al. 2012).

Social capital is further known as beneficial to nature. Barnes-Mauthe et al. (2014) find that cohesive communities are better positioned for collective action to effectively manage ecosystems. They conceptualize the relationship as bi-directional, whereby natural capital fosters social capital by facilitating interactions. We too acknowledge this bi-directionality of the relationship between social capital and nature but are constrained in analytical power to assess this explicitly. Given the greater volume of literature on the benefits from nature, we have chosen to focus on this causal direction.
Perceived nature and place attachment Existing literature purports that nature fosters place attachment. As converse examples, environmental degradation led to loss of place attachment in many parts of the world (Burley et al. 2007), and lack of natural capital in urban or built environments has seen similar impacts on human connectedness with nature (Schultz 2002; Louv 2008). Further, as expected from reports that intangible aspects of human-nature relationships are influenced by their context (Flint et al. 2013; Eastwood et al. 2016), different physical environments are likely to have differing outcomes for place attachment. Perceptions and responses of a given context will also differ for each person. Indeed, the effect of place attachment altered according to what "place," or object of attachment, respondents considered (Scannell and Gifford 2017). People who reported being attached to outdoor areas, the place type most closely associated with nature, were more likely to report psychological benefits of relaxation and activity in the area, but less likely to report practical benefits such as of provisioning ecosystem services. Similarly, studies using participatory mapping of landscape values report that different values of the landscape coincide with, and likely contribute to, greater place attachment (Brown and Raymond 2007).

\section{Study context}

For our empirical study, we chose the island city of Sado, Japan, as an illustrative case of the undervaluation of NCPs in rural communities. The community is recognized as an exemplary Satoyama-Satoumi and Globally Important Agricultural Heritage Site (GIAHS of FAO), yet struggles with a precipitous population decline from its peak of over 125,000 residents in 1950, to less than 55,000 in 2020 (Sado City Education Committee 2011; Sado City 2020). We previously demonstrated the undervaluation of Sado's natural capital using an economic metric (Inclusive Wealth Index); Sado's per capita natural capital was nonetheless roughly triple that of national averages (Yoshida et al. 2018). Here, we aim to address subjective realities of how islanders experience and value nature and NCPs that are pertinent to their wellbeing, but have yet to be included in economic evaluations of societal welfare.

\section{Materials and methods}

The questionnaire was titled "Sado's wealth and happiness" and distributed as an 8-page booklet. A description of the study was printed on the outer envelope and as an enclosed information sheet. The description also clarified that the questionnaire was voluntary and anonymous, organized by The University of Tokyo and supported by Sado City. 
Both the lead author and City office's contact details were provided.

Table 1 compiles the constructs assessed in this study, explained briefly below. All items have been translated from Japanese.

- Subjective wellbeing. Three items from differing conceptual backgrounds: single-item measures of happiness and life satisfaction commonly used to assess subjective wellbeing (Mellor et al. 2008; Veenhoven 2017), and a third item that assesses mental wellbeing in a longstanding domestic survey (Takahashi and Aramaki 2014). To minimize the influence of other questions on responses to this dependent variable, these questions were placed at the beginning of the questionnaire. A common prompt asked respondents to answer the questions about their life in general.
- Social capital. A widely used, single-item measure of generalized trust (Reeskens and Hooghe 2008).

- Loneliness. We adopted a single-item measure, considered better suited for an elderly population (Holmén et al. 1992) than the popular UCLA Loneliness Scale (Russell 1996).

- Place attachment. Five items assessing emotional aspects of place attachment were based on Williams and Vaske's (2003) questionnaire. Respondents were asked to answer the questions about their local community (chiiki), specified as "hamlet (shūraku)/group of hamlets (shūrakugun)."

- Perceived nature. Landscape values were operationalized to assess the quantity of nature. These questions specified the context as regarding the natural environment of the respondent's local community (chiiki). Responses to this measure have been verified against land cover data (Yoshida et al., Manuscript in preparation).

Table 1 Questionnaire items and descriptive results

\begin{tabular}{|c|c|c|c|c|}
\hline Concept & Item & $n$ & $M$ & $S D$ \\
\hline \multicolumn{5}{|l|}{ Subjective wellbeing } \\
\hline Happiness & All in all, I am happy right now & 529 & 3.64 & 1.07 \\
\hline Life satisfaction & All in all, I am satisfied with my life & 530 & 3.44 & 1.12 \\
\hline Sense of purpose and peace & I live with a sense of purpose, and peace and vigor of heart & 530 & 3.32 & 1.14 \\
\hline \multicolumn{5}{|l|}{ Place attachment ${ }^{\mathrm{a}}$} \\
\hline Part of me & I feel ' $\mathrm{X}$ ' is a part of me & 523 & 3.22 & 1.09 \\
\hline Special to me & ' $\mathrm{X}$ ' is very special to me & 522 & 3.27 & 1.07 \\
\hline Identify with & I identify strongly with ' $\mathrm{X}$ ' & 527 & 3.30 & 1.09 \\
\hline Attached to & I am very attached to ' $\mathrm{X}$ ' & 524 & 3.42 & 1.12 \\
\hline Incomparable & No other place can compare to ' $\mathrm{X}$ ' & 524 & 3.12 & 1.05 \\
\hline \multicolumn{5}{|l|}{ Perceived nature } \\
\hline Therapeutic & $\begin{array}{l}\text { There is a lot of natural environment that links to mental } \\
\text { and physical comfort }\end{array}$ & 526 & 3.69 & 1.01 \\
\hline Aesthetic & There is a lot of beautiful nature and sceneries & 527 & 3.92 & 0.96 \\
\hline Spiritual & $\begin{array}{l}\text { There is a lot of natural environment with spiritual or reli- } \\
\text { gious value }\end{array}$ & 523 & 3.23 & 1.02 \\
\hline \multicolumn{5}{|l|}{ Social capital } \\
\hline Trust & In general, do you think that people can be trusted? ${ }^{\mathrm{b}}$ & 521 & 3.22 & 0.93 \\
\hline Loneliness & Do you experience loneliness? ${ }^{\mathrm{c}}$ & 527 & 2.50 & 1.06 \\
\hline \multicolumn{5}{|l|}{ Human-nature relationships } \\
\hline Partner & Nature and I help each other. Nature is a partner/buddy & 501 & 3.57 & 1.10 \\
\hline Steward & $\begin{array}{l}\text { I have the obligation to maintain and manage nature and to } \\
\text { leave it for future generations }\end{array}$ & 502 & 3.73 & 1.09 \\
\hline Participant & $\begin{array}{l}\text { I am part of nature, and strongly bonded both mentally and } \\
\text { bodily }\end{array}$ & 500 & 3.40 & 1.08 \\
\hline User & My happiness depends on the blessings of nature & 504 & 3.56 & 1.08 \\
\hline
\end{tabular}

5-pt Likert scale unless otherwise specified (1: "Do not think so at all," 3: "Neither," 5: "Think so very much")

a ' $\mathrm{X}$ ' refers to place of relevance

b1: "Cannot be trusted at all," 3: "Neither," 5: "Can be very trusted."

c1: "Never," 2: "Occasionally," 3: "Sometimes," 4: "Often,” 5: "Always." 
- Ecocentrism (conceptual human-nature relationships). Four items from a previous study of US farmers (Yoshida et al. 2017) addressed ecocentric types of human-nature relationships: the most ecocentric Participant, Partner, Steward, and relatively anthropocentric User. Respondents were asked to indicate their agreement with each statement regarding their land or surrounding natural environment.

- Open-ended questions. Three open-ended questions were included toward the end of the questionnaire. The questions were, "What is Sado's wealth, to you?" "How does that wealth relate to your happiness?" and, "Free response: please write if you have any additional comments on Sado's wealth or happiness of living in Sado."

- Demographics. Questions on demography were included at the end of the questionnaire. Respondents were asked to select the most fitting response for multiple choice questions on sex, education, occupation, and household income.

Sampling was stratified by age and district with the aim of representing all Sado residents of Sado. First, we determined the sample size based on a target confidence interval of $95 \%$ and known response rates (30-45\%) to a shorter survey with a comparable target group (Table 2). Second, questionnaires were allotted proportionately by population to the city's ten districts. Third, target numbers were apportioned to age groups based on population size and representation in a previous survey, i.e., expected response rates. Finally, recipients were randomly selected by age group and district from the city's Basic Resident Register (jyümin kihon daichō), omitting those registered with a medical or care facility or residents younger than 15-year-old.

A list of the age and district groups with associated identifier numbers and sealed, numbered envelopes containing a numbered questionnaire, information sheet, and prepaid return envelope were prepared by the researchers. The list and questionnaires were sent to the Sado City Hall, where officials selected recipients, addressed the envelopes, and posted the questionnaires. Responses were received at the City Hall and forwarded to the researcher. The sub-district (aza) of residence and age of questionnaire recipients were provided by the city to enable subsequent matching with identifier numbers while protecting the residents' identity.

Structural equation modeling tests latent constructs by considering each questionnaire item rather than an aggregated variable assumed to represent that construct (Jöreskog 1970; Ullman and Bentler 2004). In a similar manner, it removes measurement error and assesses causal relationships where dependent variables may simultaneously predict another. As such, its analytical strength with complex, multidimensional phenomena drives its increasing use across both social (Goldberger 1972; Maccallum and Austin 2000; Tarka 2018) and ecological sciences (Grace 2006; Schweiger et al. 2016); we applied this technique using STATA.

Responses to open-ended questions were coded for emergent themes. Each comment was reviewed in two separate sittings to ensure that all comments were coded with the completed list of codes and for verification.

\section{Results}

\section{Respondents}

Of 1464 questionnaires sent, 7 were undeliverable and 536 were answered, resulting in a $36.8 \%$ response rate. Data were entered in Microsoft Excel by the lead author and assistants. All entries were reviewed in a different sitting than the inputting.

Table 3 summarizes demographic characteristics of the respondents alongside population statistics. Most
Table 2 Age distribution of Sado's population (2015), respondents of a prior questionnaire (2016), and recipients, respondents and response rate (rr) of the present study

\begin{tabular}{|c|c|c|c|c|c|c|c|c|c|c|}
\hline \multirow{2}{*}{\multicolumn{2}{|c|}{$\begin{array}{l}\text { Population } \\
\text { (18-79 years old) }\end{array}$}} & \multirow{2}{*}{\multicolumn{2}{|c|}{$\begin{array}{l}2016 \\
\text { respondents }\end{array}$}} & \multirow{2}{*}{\multicolumn{2}{|c|}{$\begin{array}{l}\text { Population } \\
\text { (15+ years old) }\end{array}$}} & \multicolumn{5}{|c|}{ Present study } \\
\hline & & & & & & \multicolumn{2}{|c|}{ Recipients $^{\mathrm{a}}$} & \multicolumn{3}{|c|}{ Respondents } \\
\hline Age range & $\%$ & $n$ & $\%$ & Age range & $\%$ & $n$ & $\%$ & $n$ & $\%$ & $r r(\%)$ \\
\hline 18-19 & 2 & 16 & 1 & $15-19$ & 4 & 145 & 10 & 30 & 6 & 21 \\
\hline 20-29 & 8 & 89 & 6 & $20-29$ & 6 & 133 & 9 & 27 & 5 & 20 \\
\hline 30-39 & 13 & 116 & 8 & $30-39$ & 10 & 228 & 16 & 56 & 11 & 25 \\
\hline $40-49$ & 15 & 188 & 13 & $40-49$ & 11 & 174 & 12 & 59 & 11 & 34 \\
\hline $50-59$ & 18 & 284 & 19 & $50-59$ & 14 & 213 & 15 & 73 & 14 & 34 \\
\hline $60-69$ & 24 & 419 & 28 & $60-69$ & 19 & 175 & 12 & 119 & 22 & 68 \\
\hline \multirow[t]{2}{*}{ 70-79 } & 21 & 383 & 26 & $70-79$ & 17 & 215 & 15 & 102 & 19 & 47 \\
\hline & & & & $80+$ & 18 & 181 & 12 & 68 & 13 & 38 \\
\hline
\end{tabular}

Population data: Statistics Bureau of Japan (2017)

${ }^{a}$ Recipients were selected in five age groups. Eight age groups are shown here for comparison with the 2016 questionnaire 
Table 3 Demographic characteristics of questionnaire respondents

\begin{tabular}{|c|c|c|c|c|}
\hline & $N$ & $\begin{array}{l}\text { Full sample } \\
536\end{array}$ & $\begin{array}{l}23-65 \text { years old } \\
284\end{array}$ & $\begin{array}{l}\text { Population } \\
57,255\end{array}$ \\
\hline \multirow[t]{6}{*}{ Age } & Range & 15 to 94 & 23 to 65 & 0 to $100+$ \\
\hline & $M$ & 57.6 & 48.2 & 54 \\
\hline & Median & 61.0 & 49.0 & 58.6 \\
\hline & SD & 19.7 & 12.4 & \\
\hline & Skewness & -0.5 & -0.4 & \\
\hline & $n$ & 534 & 284 & 57,255 \\
\hline Sex & Females & $54 \%$ & $50 \%$ & $52 \%$ \\
\hline \multirow[t]{4}{*}{ Household income } & $<3$ million JPY & $55 \%$ & $47 \%$ & $49 \%$ \\
\hline & 3 to $<5$ million JPY & $24 \%$ & $27 \%$ & $26 \%$ \\
\hline & $5+$ million JPY & $21 \%$ & $27 \%$ & $24 \%$ \\
\hline & $n^{\mathrm{a}}$ & 423 & 236 & 22,070 \\
\hline \multirow[t]{3}{*}{ Education } & High school or less & $68 \%$ & $55 \%$ & $79 \%$ \\
\hline & 2-year college or above & $32 \%$ & $45 \%$ & $21 \%$ \\
\hline & $n^{\mathrm{b}}$ & 487 & 272 & 51,510 \\
\hline \multirow[t]{6}{*}{ Occupation } & Employed by other & $36 \%$ & $51 \%$ & $63 \%$ \\
\hline & Self-employed & $17 \%$ & $12 \%$ & \\
\hline & Full-time housework & $10 \%$ & $9 \%$ & $20 \%$ \\
\hline & Part-time & $11 \%$ & $16 \%$ & $16 \%$ \\
\hline & Unemployed & $26 \%$ & $13 \%$ & $3 \%$ \\
\hline & $n^{\mathrm{c}}$ & 475 & 269 & 36,865 \\
\hline
\end{tabular}

Population data: Statistics Bureau of Japan (2012, 2017, 2019)

a Omitting "don't know" responses

${ }^{\mathrm{b}}$ Omitting those younger than 23 or in school

cOmitting "other" and students

respondents were middle-aged or older $(M=57.6$ years old, Median $=61.0$ years old), and roughly half $(55 \%)$ of the respondents were female. Household incomes of most respondents were under 3 million JPY, as is the case for $49 \%$ of Sado residents (Statistics Bureau of Japan 2019).

\section{Preliminary analysis}

Responses to questionnaire items are summarized in Table 1. Reliability tests and factor analyses are summarized in Table 4. For all four constructs assessed, only one factor had an eigenvalue above 1 , and alpha coefficients of Cronbach's test of reliability indicated satisfactory to high levels of internal validity. For perceived nature, a factor score was generated to aggregate the three observed measures according to their factor loadings.

\section{Structural equation modeling results}

Figure 2 reports results on the hypothesized model $(n=471)$. The model hypothesized that perceived nature positively influences subjective wellbeing through individuals' social relationships and place attachment. It further posited that the amount of one's perceived nature is positively influenced by their ecocentric human-nature relationships.

The model fits the data well, supporting all hypothesized paths of human-nature relationships. As would be expected with a sample size greater than 400 , the Chi-square test of the model's fit is significant $\left(\chi^{2}(112)=230.31\right.$, $p \leq 0.001)$. The root mean squared error of approximation (RMSEA), which penalizes for unnecessary complexity, also reports a good fit of under 0.05 (RMSEA $=0.047 ; 90 \%$ $\mathrm{CI}=0.039-0.056$ ) (Acock 2013). The model explains 88.7\% of the variability, and the coefficient of determination (CD), or $R^{2}$, for subjective wellbeing is $45.1 \%$.

The strongest determinant of subjective wellbeing was place attachment $(B=0.3, p \leq 0.001)$, followed by loneliness $(B=-0.27, p \leq 0.001)$, trust $(B=0.21, p \leq 0.001)$, and perceived nature $(B=0.15, p \leq 0.001)$. Trust had a significant effect on loneliness $(B=-0.39, p \leq 0.001)$, and was in turn influenced by perceived nature $(B=0.36, p \leq 0.001)$. Perceived nature strongly influenced place attachment $(B=0.6, p \leq 0.001)$, and was in turn influenced by ecocentric human-nature relationships $(B=0.46, p \leq 0.001)$.

As a final step, we added basic demographic characteristics as additional predictors of subjective wellbeing (Fig. 3). 
Table 4 Internal validity of construct measures

\begin{tabular}{llllll}
\hline Construct & Alpha coefficient & $\begin{array}{l}\text { Variance } \\
\text { explained }\end{array}$ & Factor loadings & Uniqueness & $n$ \\
\hline Subjective wellbeing & 0.88 & $80.4 \%$ & $0.88-0.91$ & & 527 \\
Place attachment & 0.90 & $71.4 \%$ & $0.74-0.89$ & & 515 \\
Ecocentrism & 0.87 & $72.2 \%$ & $0.83-0.89$ & & 496 \\
Perceived nature & 0.74 & $66.7 \%$ & $0.50-0.77$ & & 520 \\
Therapeutic & & & 0.76 & 0.42 & \\
Aesthetic & & 0.77 & 0.41 & \\
Spiritual & & 0.50 & 0.75 & \\
\hline
\end{tabular}

Fig. 2 Results of the structural equation model

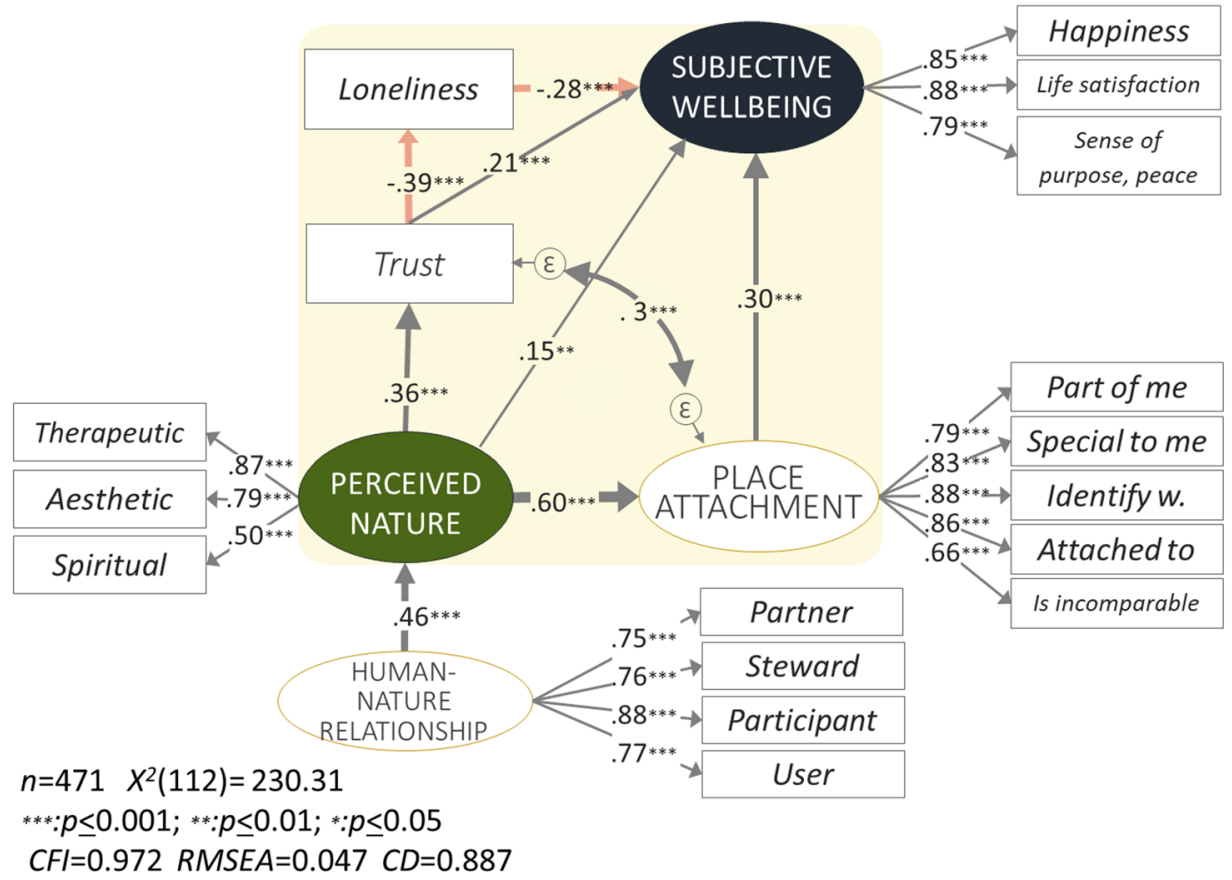

This slightly improved the fit of the model $\left(\chi^{2}(176)=315.18\right.$, $p \leq 0.001$, RMSEA $=0.046 ; 90 \%$ CI $=0.038-0.054$; $\mathrm{CFI}=0.961, n=377 ; \mathrm{CD}=90.2 \%$ ), even despite the lowered sample size after omission of incomplete or "don't know" responses on income. Place attachment's strong influence on subjective wellbeing remains unchanged $(B=0.35, p \leq 0.001)$. Log of income $(B=0.10, p=0.025)$ is a weaker predictor of subjective wellbeing than sex ( $B=0.14, p=0.002)$ or any of the perceived constructs already included in the model. Neither age $(p=0.296)$ nor education $(p=0.431)$ helps to better explain subjective wellbeing. The CD for subjective wellbeing has improved slightly, to $46.1 \%$. This finding contradicts prior reports that relied on categorical income data and found stronger regressions coefficients for income (0.3-0.5) than for social trust (0.25-0.45) (Helliwell et al. 2016b). Considering the volume of preexisting studies on the importance of loneliness or social capital for wellbeing, the stability of place attachment's statistical significance in predicting subjective wellbeing, with and without other constructs, is a noteworthy finding of our study.

\section{Respondent commentary}

Of 536 respondents, 357 responded to one or more openended prompt on Sado's wealth and their personal happiness. An overwhelming $90 \%$ of the 357 described nature and NCPs (Table 5). "Clear sky and ocean, delicious air," "experiencing the seasons in the ocean and mountains," exemplify the emphasis on intrinsic and relational values in $77 \%$ of responses. Abundance of good, fresh food was mentioned by $43 \%$. "Good rice and fish. There are many fields, so I can make anything myself. I also receive many blessings of the mountain and am truly happy. It is the source of my wellbeing," summarized one respondent. Similarly, while 
Fig. 3 Structural equation model results with demographic predictors of subjective wellbeing

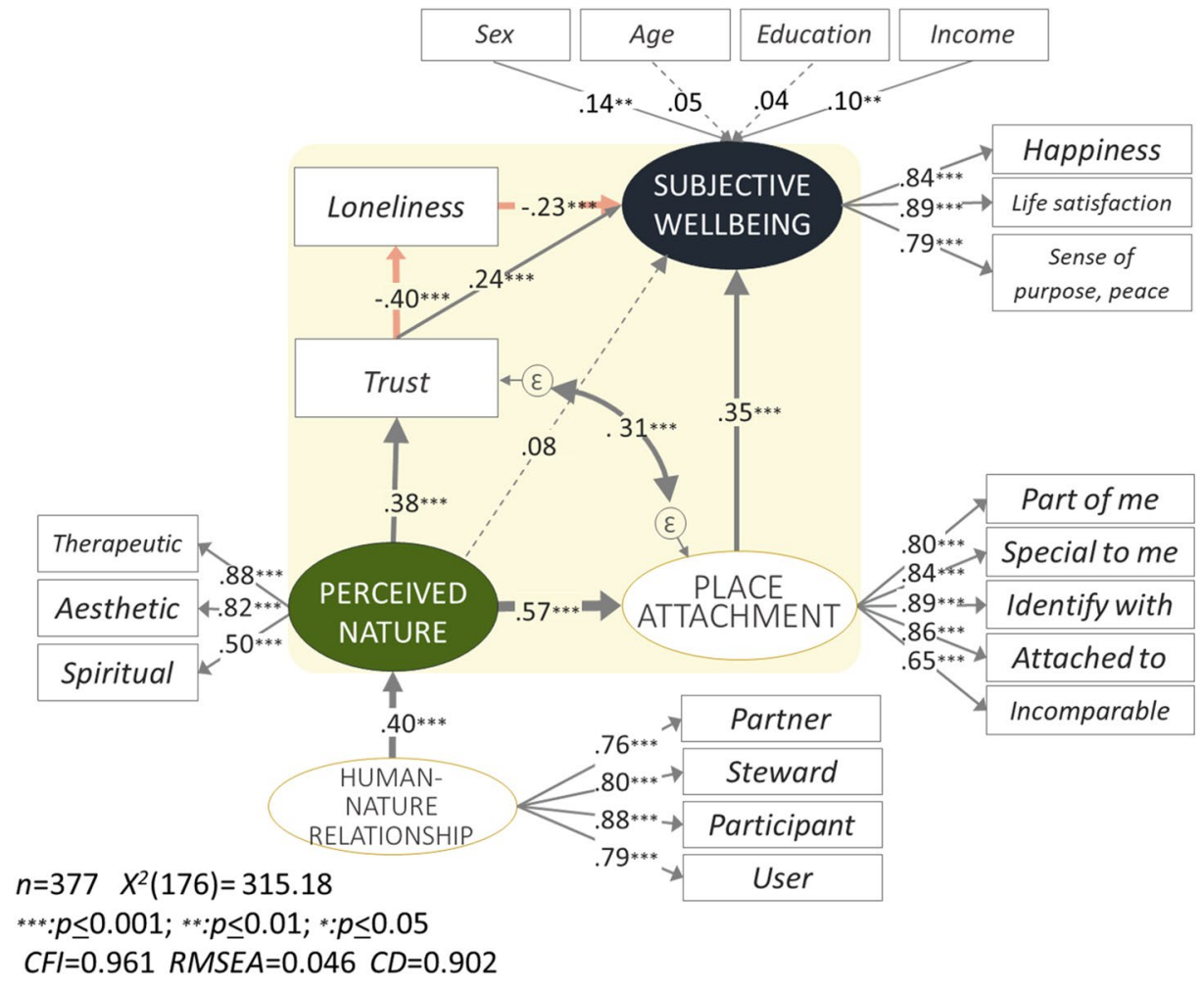

Table 5 Recurring codes and frequencies of free response comments

\begin{tabular}{lll}
\hline Codes & $n$ & $\% *$ \\
\hline Nature's contributions to people & 320 & 90 \\
Intrinsic, relational & 275 & 77 \\
Food & 155 & 43 \\
Topography, season & 80 & 22 \\
Absence of natural disasters & 19 & 5 \\
Peace of mind & 115 & 32 \\
Social capital, human character & 97 & 27 \\
History, culture & 52 & 15 \\
Comfort, safety, childrearing & 14 & 4 \\
Unhappy & 18 & 5
\end{tabular}

Total number of commenters 357

*All percentages are of the 357 responses to free response questions

7 respondents (2\%) noted low incomes or lack of employment as a concern, others elucidated along the lines of above comments, "we do not worry about basic needs even with low income ... we would never be wealthy in the stressful cities that are all about money." Indeed, 32\% of respondents described a deep peace of mind, and all but a few of these comments indicated nature as its source.

Social relationships and community, such as "warm interpersonal relationships," "helping each other," and "human character" were mentioned by $27 \%$. Though stark when mentioned, loneliness was not often mentioned in the questionnaire and generally linked with remoteness and aging. "Aging and depopulation is visibly making the community a lonely place," and "I will probably die [alone] without even entering senior housing," were some of the evocative descriptions of unhappiness by $5 \%$ of respondents.

\section{Discussion}

This study examined intangible aspects of Sado residents' relationships with nature. Our model based on field observations and literature review hypothesized social capital and place attachment as mediators of the effect of nature on subjective wellbeing. Previous studies also substantiated the role of conceptual human-nature relationships (e.g. ecocentrism) in determining people's perceptions of and behaviors regarding their environment. However, no prior study encompassed all the pieces of our analysis, and an island-wide postal questionnaire was conducted to assess these relationships. Our analysis confirmed place attachment to be a strong determinant of subjective wellbeing. The role of social capital was secondary despite the large volume of prior works on its importance to wellbeing. Our study thus breaks new ground, not only by illuminating the 
non-material ways in which nature contributes to human wellbeing, but also by highlighting the relative importance of place attachment in this context.

In addition to affirming the importance of intangible aspects of human-nature relationships to human wellbeing, the findings can be interpreted for people's role in enhancing nature. More ecocentric views of the human-nature relationship were associated with higher levels of perceived nature; other studies attest to the objective accuracy of perceptions of nature (Yoshida et al. ; Brown 2005; De Vreese et al. 2016). One explanation for this finding is that individuals' internal orientations induce differing perceptions of a given physical landscape (Van Riper and Kyle 2014). Another, drawing from past findings on the linkages between ecocentrism and pro-environmental behavior (Braito et al. 2016; Yoshida et al. 2017), would suggest that ecocentric individuals cause physical changes in the environment by contributing to the maintenance of natural landscapes. These findings elucidate how conceptual human-nature relationships contribute to both tangible and intangible ways in which we relate to nature; in other words, that ecocentrism (broadly speaking) may underlie the harmonious coexistence of humans and nature.

\section{Limitations}

We believe that our hypothesized model was theoretically and empirically justified. However, no prior work fully encompassed our model, and we necessarily relied on subjective interpretations of field visit observations and available literature. Additionally, this research focused predominantly on NCPs, i.e. flows from nature to people. While SEM is designed to assess complex, causal models, causal directionality cannot be verified by cross-sectional data (Bollen and Pearl 2013). For example, whether one's general subjective wellbeing (global life satisfaction) is the cause, or effect, of satisfaction in specific areas of life, such as work, interpersonal relationships or health, has been a topic of continued contest (Headey et al. 1991; Scherpenzeel and Saris 1996; Chmiel et al. 2012). Our focus on subjective wellbeing as the outcome variable is consistent with the more accepted interpretation in preexisting literature (Lucas 2004) but an assumption nevertheless that cannot be verified with the present data.

Findings are also subject to measurement error and selfselection of participants. Recipients of the questionnaire, particularly of a postal questionnaire such as this one, may interpret the questions in unintended ways (De Silva et al. 2006). For example, there is ambiguity regarding the radius of trust (how generalized is "general"?) (Delhey et al. 2011), and responses of Sado residents may not be comparable with responses to the question in another context. Underlining this difficulty, measurement issues with survey assessment of generalized trust have previously been suggested as an explanation of its weak explanatory power (Delhey et al. 2011). While other questionnaire items have not undergone such prior scrutiny, our measurement of perceived nature diverged from previously validated scales and may also have weakened the fit of models. Additionally, the questionnaire's title, "Sado's wealth and happiness," is likely to have guided participant self-selection and induced more optimistic responses. Critical responses made in spite of this positive framing must be taken with great weight.

\section{Implications and future directions}

The combination of place attachment, social capital and ecocentrism in investigating the linkages between nature and human wellbeing was a novel, and thus preliminary attempt. Theoretical lineages of each concept were generally independent of one another, and our findings must be further examined to assess and address their overlaps and discordances. Both theoretical and contextualized research for validation would help to further comprehend and better manage these non-material aspects of human-nature relationships.

Already, the finding that intrinsic orientations toward nature play a significant role in shaping our human-nature relationships, and that this in turn influences people's subjective wellbeing, sheds critical insight for decision makers. For one, it affirms reports on the detrimental impacts of motivation crowding (Rode et al. 2015), cautioning against nearsighted, if well-intentioned, interferences in people's human-nature relationships. More fundamentally, the fact that non-material human-nature relationships outweighed the impact of income on subjective wellbeing compels us to reconsider our societal focus on tangible realities and to further invest in addressing these intangible aspects of human-nature relationships.

Academic work has illuminated possible paths forward as we speak. Teaching local history can strengthen place attachment and related benefits including social trust and civic engagement (Stefaniak et al. 2017). Social capital is considered society's wealth, and most effectively enhanced by increasing social trust among the most disadvantaged (Helliwell et al. 2016a). Childhood exposure to nature and environmental education can enhance feelings of ecocentrism and connectedness with nature (Liefländer et al. 2013; Rosa et al. 2018).

Intangible phenomena often result from cultural and experiential factors that can be difficult to control (Fukuyama 2001). Great caution must thus be exercised to protect and nurture the intangible aspects of human-nature relationships and wellbeing. As convenient and familiar as so-called objective measures of the material world may be, we urge for greater emphasis on to the subjective realities that open new possibilities for nature-conducive development. 


\section{Conclusion}

This study affirmed hypothesized linkages between nature and good quality of life: non-material NCPs play a significant role in determining subjective wellbeing, and ecocentric human-nature relationships contribute to the upkeep of nature's values. These results lend empirical support to the understanding of human-nature interdependency in socioecological production landscapes and seascapes. In assessing the value of such regions to local residents and society at large, greater consideration should be given to non-material aspects of human-nature relationships and quality of life.

Acknowledgements The authors thank Sado City, local contacts, and participants for their time, interest and kindness in cooperating with our research.

Open Access This article is licensed under a Creative Commons Attribution 4.0 International License, which permits use, sharing, adaptation, distribution and reproduction in any medium or format, as long as you give appropriate credit to the original author(s) and the source, provide a link to the Creative Commons licence, and indicate if changes were made. The images or other third party material in this article are included in the article's Creative Commons licence, unless indicated otherwise in a credit line to the material. If material is not included in the article's Creative Commons licence and your intended use is not permitted by statutory regulation or exceeds the permitted use, you will need to obtain permission directly from the copyright holder. To view a copy of this licence, visit http://creativecommons.org/licenses/by/4.0/.

\section{References}

Acock AC (2013) Discovering structural equation modeling using stata: revised edition. Stata Press, Texas

Alessa LN, Kliskey AA, Brown G (2008) Social-ecological hotspots mapping: a spatial approach for identifying coupled socialecological space. Landsc Urban Plan 85:27-39. https://doi.org/ 10.1016/j.landurbplan.2007.09.007

Allasiw D, Yoshida Y, Sioen GB et al (2016) Field survey key informant interviews in sustainability science: Costa Rica's PES policy of changing focus from quantity to quality. In: Sustainability science: field methods and exercises. Springer, Cham, pp 41-64. https://doi.org/10.1007/978-3-319-32930-7_3

Barnes-Mauthe M, Oleson KLL, Brander LM et al (2014) Social capital as an ecosystem service: evidence from a locally managed marine area. Ecosyst Serv 16:283-293. https://doi.org/10.1016/j. ecoser.2014.10.009

Bartolini S, Sarracino F (2014) Happy for how long? How social capital and economic growth relate to happiness over time. Ecol Econ 108:242-256. https://doi.org/10.1016/j.ecolecon.2014.10.004

Baumeister RF, Leary MR (1995) The need to belong: desire for interpersonal attachments as a fundamental human motivation. Psychol Bull 117:497-529. https://doi.org/10.1037/0033-2909. 117.3.497

Biedenweg K, Scott RP, Scott TA (2017) How does engaging with nature relate to life satisfaction? Demonstrating the link between environment-specific social experiences and life satisfaction. J Environ Psychol 50:112-124. https://doi.org/10.1016/j.jenvp. 2017.02.002
Bjørnskov C (2006) The multiple facets of social capital. Eur J Polit Econ 22:22-40. https://doi.org/10.1016/j.ejpoleco.2005.05.006

Bollen KA, Pearl J (2013) Eight myths about causality and structural equation models. In: Morgan SL (ed) Handbook of causal analysis for social research. Handbooks of sociology and social research. Springer, Dordrecht, pp 301-328. https://doi.org/10. 1007/978-94-007-6094-3_15

Braito MT, Böck K, Flint C et al (2016) Human-nature relationships and linkages to environmental behaviour. Environ Values 26:365-389. https://doi.org/10.3197/096327117X1491328580 0706

Braito M, Leonhardt H, Penker M et al (2020) The plurality of farmers' views on soil management calls for a policy mix. Land Use Policy 99:104876. https://doi.org/10.1016/j.landusepol.2020.104876

Brown G (2003) A method for assessing highway qualities to integrate values in highway planning. J Transp Geogr 11:271-283. https:// doi.org/10.1016/S0966-6923(03)00004-8

Brown G (2005) Mapping spatial attributes in survey research for natural resource management: methods and applications. Soc Nat Resour 18:17-39. https://doi.org/10.1080/08941920590881853

Brown G, Raymond C (2007) The relationship between place attachment and landscape values: toward mapping place attachment. Appl Geogr 27:89-111. https://doi.org/10.1016/j.apgeog.2006. 11.002

Brown G, Reed P (2000) Validation of a forest values typology for use in national forest planning. For Sci 46:240-247. https://doi.org/ 10.1093/forestscience/46.2.240

Burley D, Jenkins P, Laska S, Davis T (2007) Place attachment and environmental change in Coastal Louisiana. Organ Environ 20:347-366. https://doi.org/10.1177/1086026607305739

Cerveny LK, Biedenweg K, McLain R (2017) Mapping meaningful places on Washington's Olympic Peninsula: toward a deeper understanding of landscape values. Environ Manage 60:643-664. https://doi.org/10.1007/s00267-017-0900-x

Cervinka R, Röderer K, Hefler E (2011) Are nature lovers happy? On various indicators of well-being and connectedness with nature. J Health Psychol 17:379-388. https://doi.org/10.1177/13591 05311416873

Chan KMA, Satterfield T, Goldstein J (2012) Rethinking ecosystem services to better address and navigate cultural values. Ecol Econ 74:8-18. https://doi.org/10.1016/j.ecolecon.2011.11.011

Chan KMA, Balvanera P, Benessaiah K et al (2016) Why protect nature? Rethinking values and the environment. Proc Natl Acad Sci 113:1462-1465. https://doi.org/10.1073/pnas.1525002113

Chmiel M, Brunner M, Martin R, Schalke D (2012) Revisiting the structure of subjective well-being in middle-aged adults. Soc Indic Res 106:109-116. https://doi.org/10.1007/ s11205-011-9796-7

Comberti C, Thornton TF, Wylliede Echeverria V, Patterson T (2015) Ecosystem services or services to ecosystems? Valuing cultivation and reciprocal relationships between humans and ecosystems. Glob Environ Chang. https://doi.org/10.1016/j.gloenvcha. 2015.07.007

De Silva MJ, Harpham T, Tuan T et al (2006) Psychometric and cognitive validation of a social capital measurement tool in Peru and Vietnam. Soc Sci Med 62:941-953. https://doi.org/10.1016/j. socscimed.2005.06.050

De Vreese R, Leys M, Fontaine CM, Dendoncker N (2016) Social mapping of perceived ecosystem services supply-The role of social landscape metrics and social hotspots for integrated ecosystem services assessment, landscape planning and management. Ecol Indic 66:517-533. https://doi.org/10.1016/j.ecolind.2016.01.048

Delhey J, Newton K, Welzel C (2011) How general is trust in "Most People"? Solving the radius of trust problem. Am Sociol Rev 76:786-807. https://doi.org/10.1177/0003122411420817 
Di Tella R, MacCulloch R, Oswald AJ (2003) The macroeconomics of happiness. Rev Econ Stat 85:809-827. https://doi.org/10.2139/ ssrn.285918

Di Tella R, MacCulloch R (2006) Some uses of happiness data in economics. J Econ Perspect 20:25-46. https://doi.org/10.1257/ 089533006776526111

Díaz S, Demissew S, Carabias J et al (2015) The IPBES conceptual framework-connecting nature and people. Curr Opin Environ Sustain 14:1-16. https://doi.org/10.1016/j.cosust.2014.11.002

Eastwood A, Brooker R, Irvine RJ et al (2016) Does nature conservation enhance ecosystem services delivery? Ecosyst Serv 17:152162. https://doi.org/10.1016/j.ecoser.2015.12.001

Ebi KL, Harris F, Sioen GB, et al (2020) Transdisciplinary research priorities for human and planetary health in the context of the 2030 agenda for sustainable development. Int J Environ Res Public Health 17:1-25. https://doi.org/10.3390/ijerph17238890

Flint CG, Kunze I, Muhar A et al (2013) Exploring empirical typologies of human-nature relationships and linkages to the ecosystem services concept. Landsc Urban Plan 120:208-217. https://doi. org/10.1016/j.landurbplan.2013.09.002

Fukuyama F (2001) Social capital, civil society and development. Third World Q 22:7-20. https://doi.org/10.1080/713701144

Gobster P, Nassauer J, Daniel T, Fry G (2007) The shared landscape: what does aesthetics have to do with ecology? Landsc Ecol 22:959-972. https://doi.org/10.1007/s10980-007-9110-x

Goldberger AS (1972) Structural equation methods in the social sciences. Econometrica 40:979-1001. https://doi.org/10.2307/ 1913851

Grace JB (2006) Structural equation modeling and natural systems. Cambridge University Press, Cambridge

Guardiola J, García-Quero F (2014) Buen Vivir (living well) in Ecuador: Community and environmental satisfaction without household material prosperity? Ecol Econ 107:177-184. https://doi. org/10.1016/j.ecolecon.2014.07.032

Guerry AD, Polasky S, Lubchenco J et al (2015) Natural capital and ecosystem services informing decisions: from promise to practice. Proc Natl Acad Sci 112:7348-7355. https://doi.org/10.1073/ pnas. 1503751112

Gullone E (2000) The biophilia hypothesis and life in the 21st century: increasing mental health or increasing pathology? J Happiness Stud 1:293-322. https://doi.org/10.1023/A:1010043827986

Hadavi S (2017) Direct and indirect effects of the physical aspects of the environment on mental well-being. Environ Behav 49:10711104. https://doi.org/10.1177/0013916516679876

Harper R (2001) Social capital: a review of the literature. Off Natl Stat $1-45$.

Hartig T, Evans GW, Jamner LD et al (2003) Tracking restoration in natural and urban field settings. J Environ Psychol 23:109-123. https://doi.org/10.1016/S0272-4944(02)00109-3

Headey B, Veenhoven R, Wearing A (1991) Top-down versus bottomup theories of subjective well-being. Soc Indic Res 24:81-100. https://doi.org/10.1007/BF00292652

Healy T, Cote S, Helliwell J, Field S (2001) The Well-Being of Nations: The Role of Human and Social Capital.

Helliwell JF, Hamilton K, Woolcock M (2016a) Social Capital, Trust and Well-Being in the Evaluation of Wealth

Helliwell JF, Huang H, Wang S (2016b) New evidence on trust and well-being. Cambridge, MA

Holmén K, Ericsson K, Andersson L, Winblad B (1992) Loneliness among elderly people living in Stockholm: a population study. $\mathrm{J}$ Adv Nurs 17:43-51. https://doi.org/10.1111/j.1365-2648.1992. tb01817.

Holtan MT, Dieterlen SL, Sullivan WC (2014) Social life under cover: tree canopy and social capital in Baltimore, Maryland. Environ Behav 47:502-525. https://doi.org/10.1177/0013916513518064
Howell AJ, Dopko RL, Passmore H-A, Buro K (2011) Nature connectedness: associations with well-being and mindfulness. Pers Individ Dif 51:166-171. https://doi.org/10.1016/j.paid.2011.03.037

Howell AJ, Passmore HA, Buro K (2013) Meaning in nature: meaning in life as a mediator of the relationship between nature connectedness and well-being. J Happiness Stud 14:1681-1696. https:// doi.org/10.1007/s10902-012-9403-x

IPBES (2019) Summary for policymakers of the IPBES global assessment report on biodiversity and ecosystem services. Bonn, Germany

Jöreskog KG (1970) A general method for estimating a linear structural equation system. ETS Res Bull Ser 2:i-41. https://doi.org/10. 1002/J.2333-8504.1970.TB00783.X

Jorgensen BS, Stedman RC (2001) Sense of place as an attitude: lakeshore owners attitudes toward their properties. J Environ Psychol 21:233-248. https://doi.org/10.1006/jevp.2001.0226

Kaplan S, Stephen K (1995) The restorative benefits of nature: toward an integrative framework. J Environ Psychol 15:169-182. https:// doi.org/10.1016/0272-4944(95)90001-2

Kates BRW, Parris TM, Leiserowitz AA (2005) What is sustainable development. Environment 47:8-21. https://doi.org/10.1080/ 00139157.2005 .10524444

Kawachi I, Kennedy BP, Lochner K, Prothrow-Stith D (1997) Social capital, income inequality, and mortality. Am J Public Health 87:1491-1498. https://doi.org/10.1084/jem.176.3.719

Kawachi I, Kennedy BP, Glass R (1999) Social capital and self-rated health: a contextual analysis. Am J Public Health 89:1187-1193. https://doi.org/10.2105/AJPH.89.8.1187

Knez I, Eliasson I (2017) Relationships between personal and collective place identity and well-being in mountain communities. Front Psychol 8:79. https://doi.org/10.3389/fpsyg.2017.00079

Konow J, Earley J (2008) The Hedonistic Paradox: Is homo economicus happier? J Public Econ 92:1-33. https://doi.org/10.1016/j. jpubeco.2007.04.006

Kurin R (2007) Key factors in implementing the 2003 convention safeguarding intangible cultural heritage. Int J Intang Herit 2:9-20

Kuroki M (2011) Does social trust increase individual happiness in Japan? Jpn Econ Rev 62:444-459. https://doi.org/10.1111/j. 1468-5876.2011.00533.x

Kweon B-S, Sullivan WC, Wiley AR (1998) Green common spaces and the social integration of inner-city older adults. Environ Behav 30:832-858. https://doi.org/10.1177/001391659803000605

Lenzerini F (2011) Intangible cultural heritage: the living culture of peoples. Eur J Int Law 22:101-120. https://doi.org/10.1093/ejil/ chr006

Lewicka M (2005) Ways to make people active: the role of place attachment, cultural capital, and neighborhood ties. J Environ Psychol 25:381-395. https://doi.org/10.1016/j.jenvp.2005.10.004

Lewicka M (2011) Place attachment: How far have we come in the last 40 years? J Environ Psychol 31:207-230. https://doi.org/10. 1016/j.jenvp.2010.10.001

Liefländer AK, Fröhlich G, Bogner FX, Schultz PW (2013) Promoting connectedness with nature through environmental education. Environ Educ Res 19:370-384. https://doi.org/10.1080/13504 622.2012.697545

Louv R (2008) Last child in the woods: saving our children from naturedeficit disorder. Algonquin Books of Chapel Hill, Chapel Hill

Lucas RE (2004) Top-Down and Bottom-Up Models of Life Satisfaction Judgments. Pap Present 6th Int Ger Socio-Econ Panel Study User Conf 4360:1-44

Maccallum RC, Austin JT (2000) Applications of structural equation modeling in psychological research. Annu Rev Psychol 51:201226. https://doi.org/10.1146/annurev.psych.51.1.201

Martín-López B, Iniesta-Arandia I, García-Llorente M et al (2012) Uncovering ecosystem service bundles through social 
preferences. PLoS ONE. https://doi.org/10.1371/journal.pone. 0038970

Matsushima M, Matsunaga Y (2015) Social capital and subjective wellbeing in Japan. Volunt Int J Volunt Nonprofit Organ 26:10161045. https://doi.org/10.1007/s11266-015-9581-3

MEA (2005) Ecosystems and human well-being: current state and trends, vol 1. Island Press, Washington, D.C.

Mellor D, Stokes M, Firth L et al (2008) Need for belonging, relationship satisfaction, loneliness, and life satisfaction. Pers Individ Dif 45:213-218. https://doi.org/10.1016/j.paid.2008.03.020

Mesch GS, Manor O (1998) Social ties, environmental perception, and local attachment. Environ Behav 30:504-519. https://doi.org/10. 1177/001391659803000405

Mitchell R, Popham F (2008) Effect of exposure to natural environment on health inequalities: an observational population study. Lancet 372:1655-1660. https://doi.org/10.1016/S0140-6736(08)61689-X

Muhar A, Raymond CM, van den Born RJG et al (2017) A model integrating social-cultural concepts of nature into frameworks of interaction between social and natural systems. J Environ Plan Manag 0568:1-22. https://doi.org/10.1080/09640568.2017. 1327424

Muradian R (2013) Payments for ecosystem services as incentives for collective action. Soc Nat Resour 26:1155-1169. https://doi.org/ 10.1080/08941920.2013.820816

Orenstein D (2013) More than language is needed in valuing ecosystem services. Bioscience 63:913-913. https://doi.org/10.1525/ bio.2013.63.12.17

Perrin JL, Benassi VA (2009) The connectedness to nature scale: a measure of emotional connection to nature? J Environ Psychol 29:434-440. https://doi.org/10.1016/j.jenvp.2009.03.003

Putnam RD (2000) Bowling alone: the collapse and revival of american community. Simon \& Schuster, New York

Reeskens T, Hooghe M (2008) Cross-cultural measurement equivalence of generalized trust. Evidence from the European Social Survey (2002 and 2004). Soc Indic Res 85:515-532. https://doi. org/10.1007/s11205-007-9100-z

Rode J, Gómez-baggethun E, Krause T (2015) Motivation crowding by economic incentives in conservation policy: a review of the empirical evidence. Ecol Econ 117:270-282. https://doi.org/10. 1016/j.ecolecon.2014.11.019

Rolston H, Coufal J (1991) A forest ethic and multivalue forest management. J for 89:35-40

Rosa CD, Profice CC, Collado S (2018) Nature experiences and adults' self-reported pro-environmental behaviors: the role of connectedness to nature and childhood nature experiences. Front Psychol 9:1-10. https://doi.org/10.3389/fpsyg.2018.01055

Rose R (2000) How much does social capital add to individual health? Soc Sci Med 51:1421-1435. https://doi.org/10.1016/S02779536(00)00106-4

Russell DW (1996) UCLA loneliness scale (Version 3): reliability, validity, and factor structure. J Pers Assess 66:20-40. https://doi. org/10.1207/s15327752jpa6601

Russell D, Peplau LA, Cutrona CE (1980) The revised UCLA loneliness scale: concurrent and discriminant validity evidence. J Pers Soc Psychol 39:472-480. https://doi.org/10.1037/0022-3514. 39.3.472

Sado City Education Committee (2011) Bunkazai sōgōteki haaku moderu jigyō hōkokusho: Sadoshi rekishi bunka kihon kōsō ( 文化財総合的把握乇デル事業報告書: 佐渡市歴史文化基本 構想) [In Japanese]. Sado

Sado City (2017) Sado shi [Sado City]. https://www.city.sado.niigata. jp/. Accessed 11 Dec 2017

Sado City (2020) No Title. https://www.city.sado.niigata.jp/. Accessed 30 Aug 2020

Sandvik E, Diener E, Seidlitz L (1993) Subjective well-being: the convergence and stability of self-report and non-self-report measures. J Pers 61:317-342. https://doi.org/10.1111/j.14676494.1993.tb00283.x

Scannell L, Gifford R (2017) The experienced psychological benefits of place attachment. J Environ Psychol 51:256-269. https://doi. org/10.1016/j.jenvp.2017.04.001

Scherpenzeel A, Saris W (1996) Causal direction in a model of life satisfaction: the top-down/bottom-up controversy. Soc Indic Res 38:161-180. https://doi.org/10.1007/BF00300457

Schippers P, van der Heide CM, Koelewijn HP et al (2014) Landscape diversity enhances the resilience of populations, ecosystems and local economy in rural areas. Landsc Ecol 30:193-202. https:// doi.org/10.1007/s10980-014-0136-6

Schultz PW (2002) Inclusion with nature: the psychology of human-nature relations. In: Schmuck P, Schultz PW (eds) Kluwer, Norwell, MA, pp 62-78; 4. https://doi.org/10.1007/ 978-1-4615-0995-0_4

Schweiger EW, Grace JB, Cooper D et al (2016) Using structural equation modeling to link human activities to wetland ecological integrity. Ecosphere 7:1-30. https://doi.org/10.1002/ecs2.1548

Seeland K, Dübendorfer S, Hansmann R (2009) Making friends in Zurich's urban forests and parks: the role of public green space for social inclusion of youths from different cultures. For Policy Econ 11:10-17. https://doi.org/10.1016/j.forpol.2008.07.005

Seymour V (2016) The human-nature relationship and its impact on health: a critical review. Front Public Heal. https://doi.org/10. 3389/fpubh.2016.00260

Shedler J, Mayman M, Manis M (1993) The illusion of mental health. Am Psychol 48:1117-1131. https://doi.org/10.1037/0003-066X. 48.11.1117

Statistics Bureau of Japan (2012) 2010 Population Census

Statistics Bureau of Japan (2017) 2015 Population Census

Statistics Bureau of Japan (2019) 2018 Housing and Land Survey of Japan

Stefaniak A, Bilewicz M, Lewicka M (2017) The merits of teaching local history: increased place attachment enhances civic engagement and social trust. J Environ Psychol 51:217-225. https://doi. org/10.1016/j.jenvp.2017.03.014

Steffen W, Richardson K, Rockstrom J et al (2015) Planetary boundaries: guiding human development on a changing planet. Science (80-). https://doi.org/10.1126/science.1259855

Sullivan WC, Kuo FE, Depooter SF (2004) The fruit of urban nature. Environ Behav 36:678-700. https://doi org/10.1177/0193841X04264945

Takahashi K, Aramaki H (2014) "Japanese Value Orientations" in a forty year time-series survey(1): from the survey on Japanese value orientations [in Japanese]. NHK Mon Rep Broadcast Res 64:2-39

Takeuchi K (2010) Rebuilding the relationship between people and nature: the Satoyama initiative. Ecol Res 25:891-897. https:// doi.org/10.1007/s11284-010-0745-8

Takeuchi K, Ichikawa K, Elmqvist T (2016) Satoyama landscape as social-ecological system: historical changes and future perspective. Curr Opin Environ Sustain 19:30-39. https://doi.org/ 10.1016/j.cosust.2015.11.001

Tarka P (2018) An overview of structural equation modeling: its beginnings, historical development, usefulness and controversies in the social sciences. Qual Quant 52:313-354. https://doi. org/10.1007/s11135-017-0469-8

Tarrant MA (1996) Attending to past outdoor recreation experiences: symptom reporting and changes in affect. J Leis Res 28:1-17. https://doi.org/10.1080/00222216.1996.11949757

Ullman JB, Bentler PM (2004) Structural equation modeling. In: Hardy M, Bryman A (eds) Handbook of data analysis. Sage Publications, London, pp 431-458

UN DESA Population Division (2019) World Urbanization Prospects: The 2018 Revision (8ST/ESA/SER.A/420). New York 
van den Born RJG (2008) Rethinking nature: public visions in the Netherlands. Environ Values 17:83-109. https://doi. org/10.3197/096327108X271969

van Reekum CM, Urry HL, Johnstone T et al (2007) Individual differences in amygdala and ventromedial prefrontal cortex activity are associated with evaluation speed and psychological well-being. J Cogn Neurosci 19:237-248. https://doi.org/ 10.1162/jocn.2007.19.2.237

Van Riper CJ, Kyle GT (2014) Capturing multiple values of ecosystem services shaped by environmental worldviews: a spatial analysis. J Environ Manage 145:374-384. https://doi.org/10. 1016/j.jenvman.2014.06.014

Veenhoven R (2017) World Database of Happiness: Archive of research findings on subjective enjoyment of life. http://world databaseofhappiness.eur.nl/hap_quer/hqi_fp.htm. Accessed 7 Dec 2017

Vemuri AW, Costanza R (2006) The role of human, social, built, and natural capital in explaining life satisfaction at the country level: toward a National well-being index (NWI). Ecol Econ 58:119133. https://doi.org/10.1016/j.ecolecon.2005.02.008

Weinstein N, Balmford A, Dehaan CR et al (2015) Seeing community for the trees: the links among contact with natural environments, community cohesion, and crime. Bioscience 65:1141-1153. https://doi.org/10.1093/biosci/biv151

White M, Smith A, Humphryes K et al (2010) Blue space: the importance of water for preference, affect, and restorativeness ratings of natural and built scenes. J Environ Psychol 30:482-493. https://doi.org/10.1016/j.jenvp.2010.04.004

Williams DR, Vaske JJ (2003) The measurement of place attachment: validity and generalisability of a psychometric approach. For Sci 49:830-840. https://doi.org/10.1093/forestscience/49.6.830

Williams DR, Patterson ME, Roggenbuck JW, Watson AE (1992) Beyond the commodity metaphor: examining emotional and symbolic attachment to place. Leis Sci 14:29-46. https://doi. org/10.1080/01490409209513155

Wilson EO (1984) Biophilia. Harvard University Press, Cambridge
Wood L, Giles-Corti B (2008) Is there a place for social capital in the psychology of health and place? J Environ Psychol 28:154-163. https://doi.org/10.1016/j.jenvp.2007.11.003

Woolcock M, Apr N (1998) Social capital and economic development: toward a theoretical synthesis and policy framework social capital and economic development: toward a theoretical synthesis and policy framework. Theory Soc 27:151-208. https://doi.org/ $10.2307 / 657866$

Yoshida Y (2013) Human-nature relationships and nutrient management practices of Illinois farmers. The University of Illinois at Urbana-Champaign, Champaign

Yoshida Y (2018) Revisiting local human-nature relationships to enhance inclusive wellbeing. The University of Tokyo, Bunkyo City

Yoshida Y, Flint CG, Dolan MK (2017) Farming between love and money: US midwestern farmers' human-nature relationships and impacts on watershed conservation. J Environ Plan Manag 61:1033-1050. https://doi.org/10.1080/09640568.2017.1327423

Yoshida Y, Matsuda H, Fukushi K et al (2018) Assessing local-scale inclusive wealth: a case study of Sado Island, Japan. Sustain Sci 13:1399-1414. https://doi.org/10.1007/s11625-018-0540-y

Yoshida Y, Matsuda H, Fukushi K, Takeuchi K Resident perceptions and land cover: how does the physical environment contribute to subjective experiences of nature?

Zhang JW, Howell RT, Iyer R (2014) Engagement with natural beauty moderates the positive relation between connectedness with nature and psychological well-being. J Environ Psychol 38:5563. https://doi.org/10.1016/j.jenvp.2013.12.013

Ziersch AM, Baum FE, Macdougall C, Putland C (2005) Neighbourhood life and social capital: the implications for health. Soc Sci Med 60:71-86. https://doi.org/10.1016/j.socscimed.2004.04.027

Publisher's Note Springer Nature remains neutral with regard to jurisdictional claims in published maps and institutional affiliations. 